\title{
263. URODZINY STANISŁAWA STASZICA W PAŁACU STASZICA \\ Warszawa, 6 XI 2018 r.
}

W dniu 6 XI 2018 r. PAN Archiwum w Warszawie po raz kolejny obchodziło uroczyście w Pałacu Staszica 263. rocznicę urodzin Stanisława Staszica, wybitnego przedstawiciela polskiego oświecenia i polskiej nauki oraz patrona siedziby naszego Archiwum. Obchody tej rocznicy rozpoczęły się tradycyjnie złożeniem kwiatów pod popiersiem jubilata i patrona pałacu. W uroczystości uczestniczyli przedstawiciele Dyrekcji PAN Archiwum w Warszawie i PAN Zakładu Działalności Pomocniczej, pracownicy tych jednostek oraz licznie zgromadzona młodzież z dwóch liceów warszawskich (CLV LO z Oddziałami Dwujęzycznymi im. Bohaterek Powstania Warszawskiego i XIV LO im. Stanisława Staszica w Warszawie) oraz przedstawicielka młodzieży z Niepublicznego Gimnazjum im. St. Staszica w Ciechocinku. Program dotyczył, oczywiście, osoby Stanisława Staszica, wybitnej postaci swoich czasów, przedstawionej z różnych perspektyw i szeroko ocenianej. Zaprezentowana sylwetka Stanisława Staszica to również historia o zwykłym człowieku i jego zaletach, wadach i słabościach. Dużym zainteresowaniem cieszył się wykład przedstawicieli Polskiej Wytwórni Papierów Wartościowych, którzy opowiadali o osobie Stanisława Staszica prezentowanego wielokrotnie na znaczkach i banknotach emitowanych przez PWPW, a także o całym procesie produkcji banknotów, jego tajnikach i obszarach powiązanych z tym zagadnieniem.

W kolejnym punkcie programu, dzięki uprzejmości Archiwum Polskiego Radia, udostępniona została audycja z cyklu Na historycznej wokandzie - Stanisław 
Staszic. Podczas audycji toczyła się polemika na temat Staszica, prowadzona przez dwóch znanych historyków, z których jeden był oskarżycielem, a drugi obrońcą Staszica. Audycja okazała się „kopalnią” merytoryczną o jubilacie, prezentując wiedzę rzadko spotykaną w opracowaniach i wydawnictwach naukowych.

W drugiej części programu zaproszona młodzież licealna prezentowała się w występach wokalnych, słowno-muzycznych oraz osiągnięciach naukowych i sportowych swojej szkoły.

Wszystkie osiągnięcia i prezentacje były gorąco oklaskiwane i świadczyły o dużym zaangażowaniu, zdolnościach, wyobraźni i pozytywnych działaniach, które przeradzają się w sukcesy młodych ludzi. 